\title{
INTRODUCTION
}

\section{The Poet Biharilal}

Biharilal (known also as Biharidas and simply as Bihari) was born about 1600 C.E., and although he inhabited a historical period that is now usually called the early modern, his poetry belongs to genres reaching back for hundreds of years and is nothing if not traditional. He composed his Satsaī (Seven Hundred Poems) in the early or middle years of the seventeenth century under the courtly patronage of Jai Singh Mirza of Amber (Amer) in Rajasthan. Though we know little more of Bihari's biography than this, his poetry is a confluence of acuity, tenderness, and artistic creativity. He writes about love and beauty, and about the condition of those who fall victim to both or either.

As we might expect with a text beginning with the personal pronoun merī("my"), a careful reading gives us real insights into the character of the poet. Of his outer life, however, we know little more than this bare sketch penned by R. S. McGregor: "Bihārīlāl, a Caturvedī (Caube) brahman, was born most probably at or near Gwalior around the year 1600 . His father, Keśavrāy, was a fine poet. Tradition ascribes to Bihārīlāl periods of residence at Vrindaban and at Agra in early life; what is certain is that he became a dependant of king Jaysiṃh [Jai Singh] Mīrzā of Amber (Jaypur [sic]: 1617-67).”1

Literary historians have tried to cut through the accre- 
tions of legend to find the provable essentials of Bihari's life. But at the same time they have been eager to promote the status of this most admired poet, and hence have been loath to depart too far from the received biography, which is hagiographical in tone and purpose. Accounts of Bihari's circumstances related by even the most respected Hindimedium literary studies are based on sources that collapse under the lightest interrogation, and we lack any hard data on which a reliable life of Biharilal could be constructed. In his wide-ranging work Kavivar Bihārī (The great poet Bihari), the celebrated Bihari scholar Jagannathdas "Ratnakar" unwittingly exemplifies this dilemma. On the one hand, he favors a commonsense discrimination of the plausible from the implausible as he sifts and evaluates various quotations from commentaries and other sources; on the other, he proceeds to relate an explicit version of Bihari's life that even purports to record individual conversations and is generally marked by an almost fairy-tale naïveté. ${ }^{2}$

At the core of the traditional version of Bihari's life is a brief verse biography in forty-eight couplets, the anonymous Bihārì-bihāra (Bihari's Roamings, or rather “A Rambler's Amble"). ${ }^{3}$ The Bihāri-bihāra recounts the main elements of the received biography, though it is impossible to say whether this is the original source or merely a compendium of legendary material. The text, written in the first person, gives an account of Bihari's life that may be summarized as follows:

Bihari was born on Wednesday, the eighth day of the light fortnight of the month of Karttik, V.S. 1654 [1597 
C.E.], in Madhupuri (Mathura). His father was Keshavdev, a Chaube brahman; his grandfather, Vasudev. At some time, Bihari's parents came to Vrindaban, and Bihari studied Sanskrit and his own vernacular as well as music and other subjects. The emperor Shah Jahan, visiting Vrindaban, was sufficiently impressed by Bihari's music $^{4}$ and poetry to invite him to court at Argalpur (Agra). There he recited ghazals, songs, and poetry to the emperor; and on the day when Shah Jahan's son was born, Bihari was called upon to recite verse to an assembly of fifty-two kings of India. The poet was rewarded with an annual stipend. He later visited the Mirza Raja of Amber, called Jai Singh or Jai Shah and known as a brilliant warrior. Initially, Bihari had no access to Jai Singh, and the royal servants would not intercede for him; he languished unregarded for two full months. But when Jai Singh became obsessed with a young queen or concubine and began ignoring affairs of state, Bihari wrote a poem [see verse 26] that was laid in Jai Singh's bedchamber; this brought the king to his senses. Jai Singh rewarded Bihari and commissioned more verses; each couplet earned him a gold coin, prompting his aspirations, and after completing the work within two months, Bihari took permission to leave the city. A bond of love drew him to Vrindaban, the center of Krishna worship. He wrote poetry for many other kings, but nowhere found the respect he had known at Jai Singh's court. Losing his taste for poetry, he took to the devotional life: "Bihari Lal" became "Bihari Das," the date of this renunciation of the world being Monday, the seventh 
day after the new moon of the month Madhumasa (Chaitra), V.S. 1742 (1685 C.E.).

The autobiographical mode of the first-person narrative is belied by the banal tone of the verses: had he written his own story, the master poet Bihari would surely have achieved something more sophisticated than the markedly humdrum account summarized in translation here. (Indeed, it might be asked why someone who has self-confessedly renounced the world would indulge in autobiography at all, especially given the lack of an autobiographical tradition in Indian literature of that period.) ${ }^{5}$ Furthermore, the chronologies expressed in the text are not borne out by almanacs of the years concerned. ${ }^{6}$ For insight into Bihari's poetry, therefore, we must turn inward to the evidence of the text itself; but this requires first knowing something about the language in which it was composed.

\section{Braj Bhasha as a Literary Language}

Braj Bhasha is the language of the Braj region, located a hundred miles to the south of Delhi. ${ }^{7}$ Places of pilgrimage within this locale, such as Vrindaban, Mathura, Govardhan Hill, and the Yamuna River, have long been associated with the Krishna narrative that forms a major current in the devotional tradition known as bhakti, which involves emotionally charged worship of the godhead. Through this Krishna connection, the supposedly rustic regional dialect of Braj Bhasha came to engender a prolific vernacular literature 
anchored in Krishna narratives. From approximately the fifteenth century, local traditions of folk song and popular hymnody were grafted onto the classical heritage of Krishna lore inherited from the Sanskrit Puranas, producing many interrelated genres of poetry. The bucolic setting of Krishna's childhood and adolescence in fondly imagined riverside groves touched Braj Bhasha with sweetness, while its performance in song tinged it with a unique musicality and lyricism (and to this day, the lyrics of Hindustani music - the north Indian tradition-are imbued with this language). In the sixteenth century, vernacular Krishna poetry reached such an ascendancy that the Braj dialect became generalized for literary purposes far from the Braj homeland and its Krishna narrative; until the Delhi dialect of Khari Boli began, in the nineteenth century, to prevail in a movement toward modernity and a growing sense of national identity, Braj Bhasha held sway as the poetic dialect par excellence right across the so-called Hindi belt of northern India.

\section{The History and Structure of the Satsaī}

The Braj Bhasha of the Satsa $\bar{\imath}$ is a literary construct, heavily influenced by the Sanskrit textual tradition but also replete with loanwords from Persian and Arabic, reflecting the influence of Mughal culture on the Rajput courts. ${ }^{8}$ And just as the language itself owes a great debt to its Sanskritic forebears, so too the tropes of the poetry derive very largely from devotional and courtly genres of earlier centuries. A particularly potent and beloved trope is the bittersweet sorrow of "love 
in separation" (viraha), which forms one of the main themes of Bihari's Satsā̃:

Your absence is a rare and matchless fire:

it flourishes in monsoon rains.

No waterfall, oh Lal, can douse its blaze. ${ }^{9}$

The poems thrive on inference, and this one rests on the interpretation of the rainy season as a cruel time when separated lovers must remain separated, travel being impossible; a further trope is that of the paradox, in which the lover's burning passion is inflamed rather than extinguished by rainfall. Rather than grouping them thematically, most recensions of Bihari's text present the poems in an apparently random order, allowing themes such as viraha to rub shoulders with lush descriptions of the heroine, caustic comments on rustic philistinism, praise of a royal patron, aphoristic statements on life generally, or observations on God's shameful failure to fulfill his mandate as savior in a troubling world.

Most of the conventions, themes, meters, and sentiments found in the text have their roots in earlier literature. The title Satsaī, perhaps bestowed by a compiler rather than by the poet himself, derives from the Prakrit word sattasai, which in turn reflects the Sanskrit saptaśatī; the meaning is "seven hundred," or "seven centuries," referring to the notional number of individual couplets constituting such a work. Many Indic texts have such numerical names, typically indicating a collection of independent stanzas whose disparate contents do not yield a descriptive title; Braj Bhasha 
itself boasts a number of Satsaīs, each a collection of poems on a set of themes, and Bihari's is among the first. The closest model for his Satsai, however, is from a much earlier time: it is the Prakrit Sattasā perhaps compiled (and partly composed?) by a monarch called Hala, who lived and ruled in the Andhra area of south India at some time in the early centuries of the Common Era. ${ }^{10}$

Several of Bihari's couplets reflect models to be found in Hala's compilation, and an example using a literal English prose translation and a contemporary English verse rendering will serve to show the depth of field behind the conventions of Braj Bhasha poetry. The English prose translation:

Oh traveller! Look here-in the mid-day even the shadow (of a man) does not slightly come out, lying hidden under the body (itself), out of fear of the Sun's heat. Why should you not then take rest (in our house)? ${ }^{11}$

A contemporary English verse translation by the poet Arvind Krishna Mehrotra humanizes the poem and makes it more comprehensible:

Afraid of midday heat, Even your shadow Stays under your feet:

Come into the shade, traveller. ${ }^{12}$

The substance may seem slight, but a well-attuned reader approaching the Prakrit poem with a sympathetic knowledge of its conventions would find much more here than 
some inconsequential chat about the weather. The poem's significance lies in an implied subtext, and the words themselves are the tip of an (unseasonal!) iceberg of meaning. The "traveller" is an actual or potential or imagined lover, and the speaker is an enamored woman who uses the summer heat as a pretext to lure him into her house. The references to "shadows" and "bodies" have a double purpose: they make a naturalistic poetic observation of the fact that shadows shrink to nothing at high noon, while their physicality hints at the sensual implication of the female speaker's wordshinting that "I would like to be where that shadow is, under your body." No names or other details attach to the protagonists, though neighboring couplets may add missing detail, deepening the reader's insight into their experiential world. The intimate symbolic connection between landscape and human relations runs deep within the poetry.

The same conceit of "shadows shrinking away at noon" appears in a couplet from Bihari's Satsaī:

Settling within the dense wood, lurking deep within the house: at summer's noon, even shadow seeks shade. ${ }^{13}$

Like its Prakrit model, the Braj poem only implies the speaker's romantic intention (without which either couplet would be little more than a high-temperature pastoral), but Bihari hides the inference even more deeply, going so far as to omit even the traveler from the tale. Thus the task of understanding an individual poem is made possible only by the reader's 
familiarity with such conceits and by the broader context of the genre as a whole. Each stanza in a text of this kind helps contextualize and explain all the others.

If Bihari subtracts from the poem's content by dropping the traveler, he adds to its depth with new allusions reflective of Braj poetics. First, his reference to the "dense wood" evokes the bucolic environment and lush setting of Radha-Krishna trysts-a narrative habitat that features very commonly in early modern vernacular poetry, as we shall see below. Second, the poem makes specific mention of the summer month Jeth, hinting at another medieval genre postdating Hala, namely the vernacular "song of the twelve months" in which romantic conceits such as the laments of separated lovers are projected onto the modulating backdrop of the annual calendar. Third, the personification of the summer heat, incipient in the Prakrit poem, where the verb "hide" suggests a sentient subject rather than an inanimate one, is taken further by Bihari with verbs such as "to settle" and "to want or seek." And fourth, Bihari's couplet uses alliteration in ways typical of Braj poetics, for example in bringing a cohesion to the final quarter of the poem, "even shade desires shade" (chẫhau cāhati chã ha), foregrounding it as a kind of punchline or key to the verse as a whole. Since the aesthetic effect of poetry derives as much from such finely worked-out effects as from the raw materials of its basic conceits, Bihari's poems are very much more than mere derivative copies of earlier originals: the vibrancy of a poem derives from its present detail rather than its past history. 


\section{Radha and Krishna as Hero and Heroine}

The amorous narratives of Radha and Krishna loom large in the Satsai, and although only about a tenth of the seven hundred couplets mention these protagonists by name, retailers of the text-commentators and artists alike-often read them into the action throughout. The Satsai is essentially a conflation of two tropes: Radha-Krishna narratives in their bucolic Braj setting, and a set of stylized "hero and heroine" motifs inherited from Sanskrit and Prakrit forebears. For the most part, individual couplets separate the two tropes of devotional and courtly or human love, as shown respectively in the following two examples:

His body blends with shadow, hers with moon;

two souls are one, as Hari and Radha

roam the lane. ${ }^{14}$

On the festival of Teej, her rivals dressed in finest garb and gems; but how their faces crumpled when they saw her rumpled clothes. ${ }^{15}$

The first of these two couplets, reflecting the divine sport of Hari (Krishna) and Radha in the groves of Braj, would not be out of place in a wholeheartedly devotional work; the second portrays love rivalries typical of ancient Indian poetical texts, including the Saptaśatītradition. But the following couplet conflates these two genres and has Shyam (Krishna) appear on the stage of a courtly drama: 
Seeing her in company, Shyam touched a lotus to his brow; she caught him in her mirror ring and held him to her heart. ${ }^{16}$

This drawing together of two narrative strands is not the work of Bihari alone but reflects the poetic interests of the so-called Rìti school of Braj Bhasha poetry, a type of aesthetic movement developed primarily by court poets in the seventeenth century. Here, revisited stylized tropes of categories of hero-and-heroine poetry merge with genres of Krishna poetry that had developed in the first major flowering of Braj Bhasha verse in the sixteenth century.

The heroine, then, is a plural or composite figure. As we have seen, she may be Radha, drawn from bhakti narratives; or she may be any one of a cast of time-honored rhetorical types such as "she whose husband is abroad", "she who has elaborately prepared for the arrival of the lover", or the "victim of unfaithfulness". ${ }^{17}$ Fair of countenance, she outshines the moon and is invisible in moonlight, though her presence is betrayed by her own fragrance; if her fair face does not lighten night's darkness, her teeth certainly will when she smiles; her fairness contrasts with Krishna's dusky coloring — for if the beloved is Radha, then the lover is Krishna. Gold is invisible against the fair skin of the heroine but is revealed by touch; a forehead mark of sandalwood that blends invisibly with her brow stands out when her skin is flushed with wine, and her white jasmine garland shows up on her chest when it withers and darkens. Thus she is innately superior to all the standard objects of comparison; 
the circumstances of these events-the touching of skin, the drinking of wine, the night-withering of flowers - all bear an erotic charge, and indeed such implicit components are often the "point" of the poems.

So slender is the heroine that the very existence of her waist is a matter of philosophical speculation; so extreme is her beauty that the inadequacy of conventional descriptive tropes itself becomes a conventional trope. Her eyes shoot coquettish arrow glances from arched brow bows. Julietlike, ${ }^{18}$ she may be on the cusp of maturity, blending girlhood with adolescent ripeness, but she becomes a consummate lover, adept in the "superior position." The agony of viraha, or love-in-separation, threatens her sanity and her life. It makes her burn with a passionate heat that even affects the local microclimate; once-happy associations now seem to her like torture, and the cooling moon scorches her.

Meetings of lover and beloved have to be contrived amid conservative social restrictions, with family elders being a particular impediment (though a husband's handsome younger brother may divert a young wife); fortunately, much can be communicated by a touch or a stolen glance, and the village setting offers potential for many fleeting encounters. Tall-standing crops make convenient trysting places-at least until harvest time. Jealous rivalries abound between co-wives striving for their shared husband's attentions, especially when a young bride joins the household, a dangerous moment for her aging rivals. Love is often personified, especially as the love god Kamdev. A favorite technique is that of the tableau, a descriptive sketch frozen in time like 
a still shot in a movie, which makes the short couplet echo long in the mind.

When offended by her lover's faithlessness, the heroine sulks with a jealous anger that her female companions, the sakhis, or go-betweens, are hard pressed to overcome. Meanwhile the sakhiss delight in noting the poorly concealed physical evidence of the lovers' clandestine escapades. Many couplets are open to several interpretations-is the heroine describing herself, or is a sakhi describing her?-and although this multivalency is essential to opening up the poetic potency of the couplets, the commentators see it as their responsibility to close it down, specifying the dramatis personae and silencing much of the semantic echo that lies at the heart of the poetic principle.

God's various roles include that of savior, and he may be chastised for failing in his supposed duty as remover of suffering; hence the occasional derogation of the divine. In a more mundane setting, many couplets read like occasional poems from the royal court, perhaps deflating pretentiousness or targeting some courtly occurrence of hubris, boorishness, or other human folly. Bihari's role as court poet is also seen in a handful of encomiums to his patron, Jai Shah; at least one couplet refers to his famous mirror-work room that tourists can still peer into - though no longer enter-in the palace at Amber. But these panegyrics seem a little dutiful, like tears forced to an actor's eye, suggesting that a laureate role may confine or chafe the creative spirit, or simply fail to inspire it. 


\section{Is the Satsai $a$ "Devotional" Work?}

As the discussion so far would lead us to expect, the greatest "pun" in the serious-but-playful Satsai is its simultaneous reference to worldliness and divinity. Although the commentators, in their tireless rote, strive to tease apart the various strands of meaning, the Satsā's tapestry is at its most resplendent when these different modes interweave freely. Devotional immanence and human experience are the warp and woof of its fabric. ${ }^{19}$ To separate the different modes of love in which sentiment inheres is to tamper with the very mechanisms of its delivery. This is the poetry of the loving spirit, and love knows no bounds.

The Satsā combines ancient tropes from Sanskritic poetry with Krishna bhakti narratives from such texts as the approximately tenth-century Bhāgavata Purāna (The Purana of the Lord $)^{20}$ and-newly featuring Radha-the twelfth-century Gìtagovinda (The Song of Govinda). ${ }^{21}$ These Sanskrit texts had spawned countless vernacular retellings well before Bihari's time, and in poetry of the Rìti school a broadening of the narrative allowed Radha and Krishna to step out of their usual habitation in Vrindaban's groves to become the archetypical hero and heroine in a wider field of love poetry. Thus although, as already noted, few of Bihari's poems name Krishna or Radha specifically, manuscript paintings regularly portray the hero and heroine in the standard iconography of the divine couple; and commentators tend to follow suit in their interpretations. When a poem describes a riverbank tryst under an autumn moon, who is to say that the unnamed hero and heroine are not this familiar pair? And when a poet invokes the agelessly appealing theme 
of viraha - the agony of separation from a beloved - who is to say whether the context is a "merely" romantic one or an expression of the soul's yearning for God? Traditional critical taxonomies thrive on clear distinctions of context, but a latent ambiguity in the meaning of things is surely a characteristic of true art, and Bihari's skill exploits this to the full. To gain as rich as possible an appreciation of his poetry, therefore, we need to be open to the widest possible range of its meanings, and to be sensitive to its music. ${ }^{22}$ Let us read a connected pair of his finest poems:

How shall Hari gain the chamber of my heart while falsehood's latch and bolt lock tight the door? ${ }^{23}$

Awakening, I see the door still chained. Then who can say how he comes in and vanishes again? ${ }^{24}$

The two poems share rhyme words and a "locked door" motif, while a shared interrogative mood gives them both a questioning wonderment. ${ }^{25}$ But a subtler kind of sharing is also involved here. The first poem features the name Hari, yielding the twin possibilities of seeing the hero as Krishna (from the perspective of his beloved) or as the supreme deity (from the perspective of a votary, or the individual soul-in other words, everyman). Unlike many other Krishna epithets that allude specifically to some personal characteristic or narrative event, the name Hari encompasses both a broader definition of Vishnu-Krishna and the abstract aspect of God 
that lies beyond mere narrative and persona; that is to say, its two dimensions allow Hari to sit comfortably with the bhakti representing the deity as respectively "qualified" and "unqualified." Thus we can read the poem as being about the physical presence and absence of Krishna the lover or as alluding to the soul's connectedness to (and woeful awareness of separation from) the divine.

If we apply this background to a reading of the beautifully constructed second poem quoted here, we begin to see that its resonance goes deeper than is commonly acknowledged by the commentators. Most of them propose a simplistic narrative in which a woman dreams of a visit from her lover, then wakes to find the door still locked from within and realizes that it was all "just a dream." This primary meaning is fine as far as it goes, but does it go far enough? Could the words not also suggest an epiphany, an apprehension of a mysterious and ineffable Presence that is felt but not seen?

Bihari's conflation of tropes is the key to his creative character, and a deep vein of wit runs through his compositions. It may occasionally be humorous, but more essentially it reflects an imaginative visionary wisdom that relates to such cognates of "wit" as the Sanskrit words vidyā, veda. This is not to imply that every couplet in the Satsai bears some kind of metaphysical profundity, or that a consistent theology (still less some tediously literal allegory) underlies poetic descriptions of female beauty; but a sensitive reading of the Satsai does yield a gift of aesthetic delight that transcends the often conventional contexts of its tropes. Unsurprisingly for a poet in the Braj Bhasha tradition, the needle of Bihari's inner compass swings very naturally to the magnetic 
north of Krishna devotionalism. But there are also moments of an intense inner quietude that suggest a personal apprehension of divine immanence on a more universal model.

The traditional critical approach to Bihari's poetry derives from the hoary and complex system of rhetoric so famously developed by the Sanskrit masters. Two facets dominate: a standardized typology of characters, narrative settings, and the like; and an elaboration of the so-called "rasa theory," in which individual "flavors" or sentiments (rasa) are borne aloft through art and are hence transformed into a kind of universalized experience of delight that transcends the specific circumstances of the moment. The rasa theory has major ramifications for such fields as philosophy, aesthetics, and devotional theology, and has been developed to a high level of rhetorical sophistication over the centuries. ${ }^{26}$ Yet the reader of English translations of Bihari is unlikely to view the poetry through this lens, and the purpose of the present book is to yield some kind of access to the poetry itself. There is much in common between Indic and Western conceptions of the functions of art. ${ }^{27}$ Both traditions recognize that the higher reaches of aesthetic experience have a sublime or spiritual dimension in which distinctions between the sacred and the profane lose their relevance. The experience of rasa, triggered by aesthetic stimuli, transcends the details of mere narrative and bears the reader to a higher plane; thus the question of whether or not a poem's dramatis personae and motifs derive from a bhakti setting becomes secondary to the artistic function of the poetic medium.

The Satsai bears witness to Biharilal as a creative individual of profound ingenuity and delightful wit; he brings 
an immediacy of experience to many a conventional image, and in so doing he reaches to us across time, allowing us direct entry to his poetic world. Though much can be said as commentary to this or that verse (and the notes to this book aim to cast light on certain allusions), the poems themselves stand up remarkably well nearly four centuries after their composition. Unsurprisingly, some work better than others in translation, and this book selects four hundred of the total 717: four centuries of poems, then, from nearly four centuries ago.

\section{Verse Structure and the Translation}

Bihari's poems are rhymed couplets written in the dohā meter and in a variant called sorthā. The dohā is a favorite meter in the Hindi tradition, found for example in genres of bhakti poetry such as the so-called sākhīs, or "witness poems," of $\mathrm{Kabir}^{28}$ and in the couplets that punctuate sequences of quatrains in the great Rāmcaritmānas of Tulsidas. ${ }^{29}$ Each line of the dohā is divided rhythmically by a caesura that falls just after the midway point-with 13 metrical beats before and 11 after the caesura-effectively dividing the couplet into four quarters or feet. The sorth $\bar{a}$ inverts this arrangement, placing the short foot before the long one, with the rhyme now falling at the caesura instead of at the end of the line; sorth $\bar{a}$ meter appears in verses 103, 138, 145, 209, 270, 323, and 329.

Since the whole of the Satsai is couched in the doha $/$ sorth $\bar{a}$ meter, a single English format is needed to maintain some structural unity throughout the corpus without proving too 
much of a metrical straitjacket. A couplet is too short and a quatrain too long; therefore, I settle upon the tercet-definable only by its three lines, not by any set metrical weight or rhyme scheme-as a viable compromise.

I welcome English rhymes when they appear serendipitously, but rhyme's function of bestowing an organic unity to the verse is more often performed by internal rhyme and alliteration - features that abound in the original - than by end rhyme. The second line of the tercet often hinges on a syntactic caesura, as though that line were a compressed form of two separate lines, but elsewhere no such caesura exists. Thus the desired unity of form running throughout my translation is quite loose, consisting simply in the disposition of three lines.

I have tried to emulate the character of the originals through a process of substitution. Since one-to-one replications of Braj puns (and other rhetorical devices) with English equivalents are largely impossible, the desideratum of "faithfulness" has to be met in terms of overall tone rather than detailed specifics. Punning allusions such as "matchless fire” (verse 27), "he truly lives who's dyed in Ram" (verse 91), and "[a knot that's] bound to yield" (verse 325) are substitutes for similar kinds of wordplay somewhere in the originals, but are themselves inventions in the target language. Variations on this technique, used equally with alliteration and rhythm, are applied throughout the translation. My focus has been on the actual moment of each poem; I have tried to suggest the inner stillness at the heart of Bihari's literary art, for his literary wit is at once light and profound.

Many aspects of the couplets, especially playfulness, 
structure, and allusions, are explained in the formal analysis offered by the notes.

\section{Acknowledgments}

The Satsā has held me in its spell since I first encountered the text through Simon Weightman's Hindi classes at the School of Oriental and African Studies in 1973, and the long intention to translate some part of it has finally borne fruit at the other end of my career, after retirement. My greatest debt of gratitude is to Sheldon Pollock, kindliest and most supportive of editors; through him alone I have the honor of contributing to the illustrious MCLI series. I have also benefited greatly from the wise advice of David Shulman, Francesca Orsini, and Eliot Weinberger at MCLI. Heather Hughes, Emily Silk, and Leslie Kriesel at MCLI have enhanced my text through their insightful editing. Many others have helped me along the way, whether with practical assistance, scholarly counsel, or more general encouragement and chiding, and I give heartfelt thanks to Marina Chellini, Rohini Chowdhury, Gopal Gandhi, Sophie Hartman, Jack Hawley, Akbar Hyder, Aruna Kharod, Janice Leoshko, Renuka Madan, Lakshmidhar Malaviya, Arvind Krishna Mehrotra, Ramkumari Mishra, the late Kunwar Narain, Patrick Olivelle, Shilpa Parnami, Bhavani Parpia, Mary Rader, Andrew Topsfield, the late Rima Treon, and Harish Trivedi.

This translation is dedicated to Renuka, with whom Biharilal himself seems also to have been well acquainted. 
1 McGregor 1984: 173.

2 Jagannathdas "Ratnakar" 1953: 314-382.

3 The text was allegedly copied by a Hindi scholar named Pandit Harprasad Caturvedi from a manuscript carried by a gentleman encountered on a train journey, and was eventually published in the Nāgarīpracārin̄i Sabhā Patrikā (Journal of the Association for the Promotion of Nagari) in 1919.

4 Had Bihari been as much of a musician as is here (and commonly) made out, his text might have been expected to be richer in musical reference.

5 The first true autobiography in Braj Bhasha-perhaps in any Indian language -is the Ardhakathānaka (Half a Tale) of Banarasidas, dated V.S. 1698 (1641 C.E.); see Chowdhury 2009 and Snell 2005.

6 Jagannathdas "Ratnakar" 1953: 321. Employing one of the standard methodologies of such historical sleuthing, Ratnakar points out a mismatch between the days of the week and lunar dates specified in the text.

7 For introductions to the language, see Snell 1991 and McGregor 1968; for an overview of its literature see McGregor 1984; and for its courtly traditions see Busch 2011.

8 See Miltner 1961 and Busch 2010.

9 Verse 27.

10 See Khoroche and Tieken 2009 for a discussion of the possible dates of the Sattasai of Hala.

11 Basak 1971: 12.

12 Mehrotra 1991: 5.

$13 \quad$ Verse 82.

14 Verse 386.

15 Verse 197.

16 Verse 14.

17 See Rākeśagupta 1967 and Gerow 1971.

18 Capulet: "She hath not seen the change of fourteen years"-Romeo and Juliet 1.II.9.

19 See Snell 1994 for a fuller discussion.

20 Bryant 2003.

21 Jayadeva 1977.

22 See Miltner 1963 for a discussion of Bihari's musicality. 
23 Verse 226.

$24 \quad$ Verse 257.

25 The rhyme kapāta/bāța (and its rhetoric) has a precedent in Rāmcaritmānas, Sundarkānd 30. See Tulsidas 2020: 260.

26 Many of the primary texts for rasa theory are presented in Pollock 2016.

27 There are also countless major divergences in the two critical systems. Repetition of a word is regarded as a poetic fault (punarokti doșa) in the Indic tradition, whereas the modern English poet and theorist Glyn Maxwell (2013: 53) can say, "Regarding repetition, there is none in poetry"-meaning that the second occurrence of a word lacks virginity and therefore has a new and different semantic character.

28 See Vaudeville 1974.

29 See Tulsidas 2016-2023. 